\title{
The Impact of Capital Structure on Financial Performance of Consumer Goods Industry in Nigeria
}

\author{
Muhammad Usman \\ Abban Gafai Education Resource Centre Katsina, Katsina, Nigeria \\ Email: usmanmuhammad27@gmail.com
}

How to cite this paper: Usman, M. (2019) The Impact of Capital Structure on Financial Performance of Consumer Goods Industry in Nigeria. Open Journal of Accounting, 8, 47-62.

https://doi.org/10.4236/ojacct.2019.84004

Received: October 9, 2019

Accepted: October 28, 2019

Published: October 31, 2019

Copyright $\odot 2019$ by author(s) and Scientific Research Publishing Inc. This work is licensed under the Creative Commons Attribution International License (CC BY 4.0).

http://creativecommons.org/licenses/by/4.0/

\begin{abstract}
The study aims to examine the impact of capital structure on the financial performance of the consumer goods industry in Nigeria. The population of the study comprised of the consumer goods companies listed on the Nigerian Stock exchange with a Sample size of six (6) companies, using filter as a sampling technique of which a period of five (5) years was used from 2012-2016. The Dependent variable of the study is financial performance proxied by return on asset (ROA), while the independent variables of the study are: Long term debt (LTD), Short term debt (STD) and shareholders' funds (ROE). The data generated from annual report and accounts of the selected companies were analyzed by means of descriptive statistics, correlation and regression analysis using E-views 8.0. The result of the analysis was tested at 0.05 (5\%) level of significance. The findings of the study show that Short term debts have no significant impact on the financial performance of listed firms in the Nigeria consumer goods industry. It was also discovered that Long term debts have no significant impact on the financial performance of listed firms in the Nigeria consumer goods industry. It was also discovered that Equity has significant impact on the financial performance of listed firms in the Nigeria consumer goods industry. The study recommended that in making a decision on what the composition of their capital structure will be, companies should look critically and make comparison between the cost of obtaining a particular source of capital and the benefit that can be derived from it instead of making capital structure decisions on baseless generalizations. This will help managers ensure that there will be a gain at the end of the day.
\end{abstract}

\section{Keywords}

Debt, Equity, Return on Asset, Return on Capital Employed 


\section{Introduction}

Capital structure constitutes a substantial part of an organization and therefore, the way in which it is managed will have a significant impact on the profitability of the company concerned. A financial expert [1] differentiated between capital structure and financial structure. He asserted that the various means used to raise funds represented the financial structure of the enterprise. He defined capital structure as the proportionate relationship between long-term debt and equity.

Financial performance in broader sense refers to the degree to which financial objectives begin or has been accomplished and is an important aspect of finance risk management. It is the process of measuring the result of a firm's policies and operation in monetary terms. It is used to measure firm's overall financial health over a given period of time and can also be used to compare similar firms across the same industry or to compare industries or sector in aggregation.

Consumer goods sector is a category of stock and companies that relate to items purchased by individual rather than manufacturers and industries. This sector includes companies involved with food production, packaged goods, clothing, beverages, automobiles and electronics. The performance in the consumer goods sector depends heavily on consumer behaviour. When the economy grows, the sector will see an increased demand for higher end product. When the economy shrinks, there is an increased demand for value product. While some product types such as food are necessary, others, such as automobiles, are considered luxury items.

Capital structure is the combination or mixture of the company's equity and debt, which ensures financial stability, profit generation, growth and expansion. [2] views the capital structure of a company as the precise mixture of debt and equity used in financing the firm's operation. Capital structure means the approach a firm uses in financing their assets through the mixture of debt, and equity or hybrid securities [3]. Hybrid securities in this content mean a group of securities that combine the elements of both debt and equity, which have fixed or floating rate of return, and the holder has the option of converting it into the underlying company's share. Capital structure is a mixture of a company's debt (long term and short term) [4].

\subsection{Statement of the Research Problem}

The choice of capital structure is fundamentally a marketing problem. In the case of Nigeria, the capital structure decision is crucial, as the decision becomes even more difficult, in times when the economic environment in which the company operates presents a high degree of instability (like the case of Nigeria). The firm can issue dozens of distinct securities in countless combination, but it attempts to find the particular combination that maximizes its overall market value [5]. The capital structure to be adopted by a business or organization is a critical decision for the management to make, the decisions are both critical and 
crucial because of the need to maximize returns to various organizational constituencies and the impact such decision has on an organization's ability to deal with its competitive environment. It is left to a company to decide to finance its investment either by debt and/or equity. This critical financial decision will have an effect on the debt/equity ratio (debt-equity mix) of the firm. The implication of this debt-equity mix is evident in, but not limited to the shareholders' earnings, cost of capital and the market value of the firm which is affected by the risk involved.

\subsection{Objective of the Study}

This study is aimed at examining the impact of capital structure on the financial performance of consumer goods industry in Nigeria. In achieving this objective, the following objectives are to examine the impact of:

1) Short Term Debt on financial performance of consumer goods industry in Nigeria.

2) Long Term Debt on financial performance of consumer goods industry in Nigeria.

3) Equity on financial performance of consumer goods industry in Nigeria.

\section{Literature Review}

\subsection{Concept of Capital Structure}

Capital structure has been defined by numerous knowledgeable individuals.

According to Van Horne and [6] defined capital structure as the mix (or proportion) of a firms" permanent long term financing represented by debt, preferred stock and common stock equity, he consider debt and equity financing as major component of capital structure. [7] stated that the firm capital structure implies the proportion of debt and equity in the total capital structure of the firm. This view is also shared by [8] where he defined capital structure of the company to be how the company finances its operations. According to him, the means a finance are usually made up of three sources which include the ordinary share capital, the preference share and the debt capital.

The capital structure decision is significant as it affect the cost of the capital and market value of the firm. According to [9], under favorable economic condition, increase in debt capital that is referred as leverage also increase earnings per share to the equity holders, That is, even though leverage cannot change the total expected earning of the firms, it can affect the residue earning to the shareholder.

\subsection{Types of Capital Structure}

The nature of capital structure adopted by different firms' varies. [10], categorized capital structure into (3) three:

1) Zero Geared or Zero Leveraged Capital Structure: Zero leveraged capital structure means the absence of any form of leverage in the capital structure. It 
indicates that there is no element of debt in the financing of the firm's operation. Here, the firm prefers to go all equity financing and forfeits the positive aspect to debt financing which boosts residual owners wealth.

2) Low Geared or Low Leveraged Capital Structure: Low leverage capital structures have a low debtlequity ratio. This indicates that residual owner's contribution (equity) higher than the claims of creditors in the business. This is most times regarded as a satisfactory capital structure.

3) High Geared or High Leveraged Capital Structure: A firm is said to be high leveraged if the contribution of the creditors is higher than that of equity holders. This type of capital structure will enhance the earning of ordinary shareholders when the cost of debt is less than the firm's overall rate of return on investment.

[11], contributed to the possible types of capital structure by stating that the debt -equity mix can take any of the following forms: $100 \%$ equity: $0 \%$ debt, $0 \%$ equity: $100 \%$ debt and $\mathrm{X} \%$ equity Y\% debt, from these three alternatives, option one is that of the unlevered firm that is the firm avoids the advantage of leverage if any. Option two may not actually be realistic or possible in real life of economic situation because no provider of funds will invest his money in a firm without equity capital. Option three is the most realistic one, in that it combines both a certain percentage of debt and equity in the capital structure and thus, the advantages of leverage [11].

\subsection{Importance of Capital Structure}

The importance of designing a proper capital structure is explained below:

Value Maximization; Capital Structure maximizes the market value of a firm, i.e. in a firm having a properly designed capital structure the aggregate value of the claims and ownership interest of the shareholders are maximized

Cost Minimization; Capital Structure minimizes the firm's cost of capital or cost of financing. By determining a proper mix of fund sources, a firm can keep the overall cost of capital to the lowest.

Increase in Share Price; Capital Structure maximizes the company's market price of share by increasing earnings per share of the ordinary shareholders. It also increases dividend receipt of the shareholders.

Investment Opportunities; Capital structure increases the ability of the company to find new wealth creating investment opportunities. With proper capital gearing it also increases the confidence of suppliers of debt.

Growth of the Country; Capital structure increases the country's rate of investment and growth by increasing the firm's opportunity to engage in future wealth creating investment.

\subsection{Element of Capital Structure}

A company formulating its long term financial policy should analyze its current financial structure. In the process of analysis, the following element of a compa- 
ny's capital structure should be explained in detail [12].

\section{1) Maturity and priority}

The maturity of securities used in the capital mix may differ. Equity is the most permanent capital within debt; commercial paper has the shortest maturity and longest public debt. Similarly, the priority of securities also differs. Capitalized debt like lease or hire purchase finance is quite safe from the lender point of view and the value of assets backing the debt provides the protection of the lender.

\section{2) Financial Innovation}

Firms may raise capital either through the issues of simple securities or through the issues innovative securities. Financial innovations are intended to make the security issue attractive to investors and reduce cost of capital. For example a company may issue convertible debenture at a lower rate rather than non-convertible debenture at a relatively higher interest rate. A further innovation could be that the company offer higher simple interest rate on debentures and offer to convert interest amount into equity.

\subsection{Concept of Financial Performance}

The phase "performance" is a concept of two tires, namely efficiency and effectiveness. While efficiency is the ratio between input and output, effectiveness is the degree of goal achievement for an organization. According to the motivation theory in management science, performances is interpreted as "a price of work completed by an employee" [13].

According to [14], operating performance is the degree of a company achieving its strategic goals, as well as indicator for the examination of the company's overall competiveness. When conducted properly, the evaluation of organization performance will give an organization's manager an idea of current condition of his/her organization. The evaluator indicators used the most often are an organization's income, production capacity and profitability.

\subsection{Review of Empirical Studies}

Many of these studies have been undertaken home and abroad on this area. Some of these studies will be discussed in this section and make this section easier. The following studies were undertaken locally in Nigeria.

[15] carried a study on determinants of firm's financial performance, using the textile sector of Pakistan for their study, and found that firm's performance is significantly affected by short - term leverage, size, risk, tax and non - debt tax shield.

[16] investigated the relationship between capital structure and firm performance across different industries using a sample of Jordanian manufacturing firm. The annual financial statements of 45 manufacturing firm listed on the Amman Stock Exchange were used for the study and covered a period of five (5) years, 2005-2009. He used multiple regression analysis on performance indica- 
tors such as return on asset (ROA) and profit margin (PM) as well as short term debt to total assets (STDTA), long term debt to total assets (LTDTA) and total debt to equity (TDE) as capital structure variables. The results showed that there is a negative and significant relationship between STDTA and LTDTA and ROA and PM; while TDE is positively related with ROA and negatively related with PM. STDTA is significant using ROA and PM. STDTA is significant using ROA while LTDTA is significant using PM. His final conclusion is that statistically, capital structure is not a major determinant of firm performance.

[17] using the data available studied the effect of the following on capital structure; size, profitability, tangibility, growth opportunities, tax, non-debt tax shields, volatility, and industry classification. He concluded that leverage is positively correlated with size while leverage is negatively correlated with profitability. There was also a negative relation between tangibility and leverage. The relationship between leverage and $\mathrm{P} / \mathrm{B}$ ratio (Proxy for growth opportunities) is negative which means that firms with higher future growth opportunities should use more of equity financing. It was discovered that leverage is positively correlated with tax and it is negatively correlated with non-debt tax shields. No relationship was found between leverage and volatility.

[18] studied the impact of capital structure on firm performance using Information Technology companies listed on Shanghai and Shenzhen stock exchange as sample. They discovered a negative correlation between company's capital structure and profitability.

[19] carried a study on effect of capital structure on financial performance of listed commercial banks in Kenya and found that capital structure of listed commercial banks in Kenya is significant and affect financial performance of commercial banks negatively

[20] in their study, titled "Comparison of impact from capital structure to corporate performance between Chinese and European listed firms" using data from more than 1200 listed companies in Germany and Sweden and more than 100 listed companies in China covering the period 2003-2012, found that capital structure has a significant negative effect on firm performance in China, whereas, significant positive effect in 2 European countries before financial crisis happened in 2008.

[21] examined the impact of capital structure choice on firm performance in Egypt, using a multiple regression analysis in estimating the relationship between leverage level and firm's performance, the study cover between 1997 and 2005. Three accounting based measures of financial performance (return on Equity, return on Assets and gross profit margin) were used. The result revealed that capital structure choice decision in general, has a weak to-no impact on firm's performance.

[22] used panel data techniques to investigate the relationship between firm's capital structure and its performance. [23] applies a pooled ordinary least square regression on 36 engineering sector firms in Pakistan. Results indicate a signifi- 
cantly negative relationship between the firm's performance measured by the return on assets, gross profit margin and Tobin's $Q$, while a negative but not statistical significant relationship between financial leverage and firm performance measured by the return on equity.

[24] examined the impact of capital structure on financial performance of listed trading companies in Sri Lanka. They extracted data from the annual reports of the sample companies from 2006 to 2010. Correlation and multiple regression analysis were used for their analysis. They found out that there is a positive relationship between capital structure and financial performance. They also discovered that capital structure's significant impact on financial performance of the firm showed that debt asset ratio, debt-equity ratio and long-term debt correlated with gross profit margin (GPM), net profit margin (NPM), Return on capital employed (ROCE), Return on Asset (ROA) and Return on Equity (ROE) at significant level of 0.05 and 0.1 .

\subsection{Statement of Hypothesis}

For the purpose of this study, the following hypotheses were formulated in line with the specific objectives.

1) H0: Short term debt does not have significant impact on the financial performance of listed firms in the Nigeria consumer goods industry.

2) H0: Long term debt does not have significant impact on financial performance of listed firms in the Nigeria consumer goods industry.

3) HO: Equity does not have significant impact on financial performance of listed firms in the Nigeria consumer goods industry.

\section{Methodology}

This study utilized the ex-post factor research design as it attempts to utilize published documents because the study would only involve the use of secondary data generated from annual report and accounts of consumer goods industry that are quoted with the Nigeria Stock Exchange (NSE) as at $31^{\text {st }}$ December, 2016. The researcher used secondary source of data for the purpose of this study. Five years (2012-2016), annual reports and accounts were obtained from relevant sources and Nigerian stock exchange (NSE).

The population of this study consists of 14 companies quoted on the Nigerian stock exchange under the consumer goods industry. The researcher used filter as sampling technique and selected a number of six (6) companies from the population. The researcher considers some subject of the population as typical cases which are most likely to provide the requisite information that meets the time frame for the research and aids to generalize the findings of the study will be utilize with consistent with.

The researcher analyses the data extracted from financial statements of selected consumer goods industries. The common techniques for analysis that are used in research include descriptive statistics, compliance index, chi-square, 
students' T-test, correlation coefficient, and multiple regressions among others. However, for the purpose of this work, the researcher decides to make use of linear regression analysis to test hypotheses and arrive at a logical conclusion. The researcher employed linear regression as tool of analysis and one of the most popular and common statistical techniques use in social sciences.

\subsection{Variables and Their Measurement}

There are two sets of variables covered by this study. These are the dependent and independent variables.

Dependent Variables

The dependent variable is financial performance which is proxies using measures of Return on Assets (ROA) to determine firm performance. The accounting measures represent the financial ratios for balance sheet and income statements.

Return on Asset (ROA): measures profits against all the asset of the company uses to make its earnings. It shows the percentage of profit that a corporation earns in relation to its overall resources, an increasing ROA indicates that a firm generates more profitability while decreasing ROA indicates that a firm generates less profitability.

$\mathrm{ROA}=$ net profit after tax/total assets

\section{Independent variables}

The researcher used component of capital structure as independent variables, short-term debt, long-term debt as a ratio of total assets and shareholder fund (equity).

1) Short Term Debts (STD): These are liabilities due for repayment within a year.

2) Long Term Debts (LTD): These are liabilities due for payment for more than a year.

3) Shareholders' Funds (SHFND): This is the difference between the total value of assets and total value of liabilities

Model Specification

$$
Y=a+b_{1} x_{1}+b_{2} x_{2}
$$

The regression equation of this study is expressed as

$$
\begin{gathered}
\operatorname{Per} f=f(\mathrm{STD}) \\
\operatorname{Per} f=f(\mathrm{LTD}) \\
\operatorname{Per} f=f(\mathrm{EQTY}) \\
\operatorname{Per} f=f(\mathrm{STD}+\mathrm{LTD}+\mathrm{EQTY}) \\
\operatorname{Per} f_{i t}=f\left(\beta_{0}+\beta_{1} \mathrm{STD}_{i t}+\beta_{2} \mathrm{LTD}_{i t}+\beta_{3} \mathrm{EQTY}_{i t}+e_{i t}\right)
\end{gathered}
$$

The equation above is estimated using the regression based frame work Ordinary least square (OLS).

Where:

$\mathrm{ROA}=$ Return on Asset 
$\beta_{0}=$ Intercept

LTD $=$ Long Term debt

$\mathrm{EQTY}=$ Equity

$\mathrm{AGE}=$ the number of years since listed on the stock exchange

$\beta_{1} \beta_{2} \beta_{3}=$ are the slopes

$e_{i t}=$ Is the stochastic variables.

\subsection{Data for the Analysis}

\begin{tabular}{|c|c|c|c|c|c|c|}
\hline $\mathrm{S} / \mathrm{N}$ & ROA & ROE & STD & LTD & AGE & EQT \\
\hline 1 & 0.14 & 36.36 & $29,354,910$ & $8,513,058$ & 47 & $40,352,504$ \\
\hline 2 & 0.10 & 25.77 & $42,737,998$ & $8,796,183$ & 48 & $46,039,111$ \\
\hline 3 & 0.07 & 21.25 & $38,552,684$ & $27,429,985$ & 49 & $45,061,717$ \\
\hline 4 & 0.06 & 16.13 & $39,921,635$ & $12,250,754$ & 50 & $48,341,376$ \\
\hline 5 & -0.01 & -4.84 & $62,663,423$ & $14,034,546$ & 51 & $41,660,605$ \\
\hline 6 & 0.03 & 16.28 & $28,579,668$ & $2,313,776$ & 26 & $10,307,595$ \\
\hline 7 & 0.05 & 22.21 & $26,896,882$ & $4,997,684$ & 27 & $12,577,980$ \\
\hline 8 & 0.12 & 37.13 & $15,871,803$ & $1,433,469$ & 28 & $17,328,695$ \\
\hline 9 & 0.11 & 29.77 & $31,083,848$ & $4,433,469$ & 29 & $23,933,633$ \\
\hline 10 & 0.05 & 13.51 & $33,258,232$ & $1,520,205$ & 30 & $24,779,594$ \\
\hline 11 & 0.09 & 17.24 & $16,242,435$ & 0.00000 & 36 & $20,039,356$ \\
\hline 12 & 0.14 & 25.10 & $13,541,296$ & 0.00000 & 37 & $23,994,931$ \\
\hline 13 & 0.07 & 16.76 & $11,742,702$ & 153,243 & 38 & $12,749,451$ \\
\hline 14 & 0.04 & 9.39 & $11,104,368$ & 0.00000 & 39 & $12,285,297$ \\
\hline 15 & -0.01 & -2.68 & $12,718,086$ & 0.0000 & 40 & $11,056,734$ \\
\hline 16 & 0.15 & 40.71 & $61,692,692$ & $45,000,000$ & 39 & $93,447,892$ \\
\hline 17 & 0.17 & 38.34 & $69,832,649$ & $9,000,000$ & 40 & $112,359,185$ \\
\hline 18 & 0.12 & 24.73 & $83,513,452$ & $24,670,000$ & 41 & $171,964,263$ \\
\hline 19 & 0.11 & 22.08 & $107,460,990$ & 0.000000 & 42 & $172,321,503$ \\
\hline 20 & 0.08 & 17.13 & $112,054,921$ & $17,000,000$ & 43 & $165,913,768$ \\
\hline 21 & 0.16 & 56.81 & $19,312,035$ & 145,183 & 39 & $10,043,524$ \\
\hline 22 & 0.11 & 49.87 & $26,690,176$ & 782,074 & 40 & $9,639,695$ \\
\hline 23 & 0.05 & 32.26 & $31,125,307$ & 762,602 & 41 & $7,478,808$ \\
\hline 24 & 0.02 & 14.90 & $34,505,057$ & 591,055 & 42 & $8,003,253$ \\
\hline 25 & 0.04 & 26.28 & $52,977,778$ & 414,275 & 43 & $11,689,943$ \\
\hline 26 & 0.06 & 18.90 & $40,350,298$ & 276,066 & 34 & $49,996,000$ \\
\hline 27 & 0.03 & 9.14 & $99,331,923$ & $39,863,248$ & 35 & $82,485,250$ \\
\hline 28 & 0.02 & 6.42 & $114,559,458$ & $48,614,076$ & 36 & $83,559,432$ \\
\hline 29 & 0.02 & 9.69 & $156,501,229$ & $55,260,645$ & 37 & $87,410,395$ \\
\hline 30 & 0.04 & 15.06 & $167,660,360$ & $48,009,715$ & 38 & $95,765,774$ \\
\hline
\end{tabular}

Source: Generated by the researcher from annual report and account of the sampled companies. 


\section{Result and Test of Hypotheses}

Table 1 shows that STD has a positive relationship of 2.75 with ROS and the p-value of STD shows the perfect relationship of 0.8346 and the relationship is insignificance because the p-value is greater than 0.05 (5\%) level of significance.

\section{Hypothesis I}

$\mathrm{H}_{01}$ : Short term debt does not have significant impact on the financial performance of listed firms in the Nigeria consumer goods industry.

Based on the above analysis, there is positive relationship between Short term debt and return on asset because the R-square and adjusted R-square are greater than $50 \%$ level of significance as shown in the above analysis which is $70 \%(0.70)$ and $67 \%(0.67)$ respectively, with positive p-value of 0.8346 which is greater than $5 \%$ level of significance, so the null hypothesis is thereby accepted. It is therefore concluded that Short term debts have no significant impact on the financial performance of listed firms in the Nigeria consumer goods industry.

Table 2 shows that LTD has a positive relationship of 3.75 with ROS and the p-value of STD shows the perfect relationship of 0.9059 and the relationship is insignificance because the p-value is greater than 0.05 (5\%) level of significance.

\section{Hypothesis II}

$\mathrm{H}_{02}$ : Long term debt does not have significant impact on financial performance of listed firms in the Nigeria consumer goods industry.

Based on the above analysis, there is positive relationship between Long term

Table 1. Regression Result of STD and ROA.

\begin{tabular}{|c|c|c|c|c|}
\hline \multicolumn{5}{|l|}{ Dependent Variable: ROA } \\
\hline \multicolumn{5}{|l|}{ Method: Least Squares } \\
\hline \multicolumn{5}{|l|}{ Date: $12 / 21 / 17$ Time: $12: 04$} \\
\hline \multicolumn{5}{|l|}{ Sample: 130} \\
\hline \multicolumn{5}{|l|}{ Included observations: 30} \\
\hline Variable & Coefficient & Std. Error & t-Statistic & Prob. \\
\hline STD & $2.75 \mathrm{E}-11$ & $1.30 \mathrm{E}-10$ & 0.210972 & 0.8346 \\
\hline $\mathrm{C}$ & -0.010636 & 0.034180 & -0.311175 & 0.7581 \\
\hline AGE & 0.000426 & 0.000818 & 0.520308 & 0.6073 \\
\hline ROE & 0.003037 & 0.000398 & 7.632504 & 0.0000 \\
\hline R-squared & 0.703110 & \multicolumn{2}{|c|}{ Mean dependent var } & 0.074333 \\
\hline Adjusted R-squared & 0.668854 & \multicolumn{2}{|c|}{ S.D. dependent var } & 0.050013 \\
\hline S.E. of regression & 0.028780 & \multicolumn{2}{|c|}{ Akaike info criterion } & -4.134711 \\
\hline Sum squared resid & 0.021535 & \multicolumn{2}{|c|}{ Schwarz criterion } & -3.947885 \\
\hline Log likelihood & 66.02067 & \multicolumn{2}{|c|}{ Hannan-Quinn criter. } & -4.074944 \\
\hline F-statistic & 20.52486 & \multirow{2}{*}{\multicolumn{2}{|c|}{ Durbin-Watson stat }} & 0.566075 \\
\hline Prob(F-statistic) & 0.000000 & & & \\
\hline
\end{tabular}

Source: Generated by the researcher from annual reports 2012-2016 using E-view version 8.0. 
Table 2. Regression Result of LTD and ROA.

\begin{tabular}{|c|c|c|c|c|}
\hline \multicolumn{5}{|l|}{ Dependent Variable: ROA } \\
\hline \multicolumn{5}{|l|}{ Method: Least Squares } \\
\hline \multicolumn{5}{|l|}{ Date: $12 / 21 / 17$ Time: $12: 06$} \\
\hline \multicolumn{5}{|l|}{ Sample: 130} \\
\hline \multicolumn{5}{|l|}{ Included observations: 30} \\
\hline Variable & Coefficient & Std. Error & t-Statistic & Prob. \\
\hline LTD & $3.75 \mathrm{E}-11$ & $3.14 \mathrm{E}-10$ & 0.119355 & 0.9059 \\
\hline $\mathrm{C}$ & -0.009768 & 0.033833 & -0.288703 & 0.7751 \\
\hline AGE & 0.000435 & 0.000817 & 0.532637 & 0.5988 \\
\hline ROE & 0.003026 & 0.000394 & 7.673861 & 0.0000 \\
\hline R-squared & 0.702765 & \multicolumn{2}{|c|}{ Mean dependent var } & 0.074333 \\
\hline Adjusted R-squared & 0.668468 & \multicolumn{2}{|c|}{ S.D. dependent var } & 0.050013 \\
\hline S.E. of regression & 0.028797 & \multicolumn{2}{|c|}{ Akaike info criterion } & -4.133548 \\
\hline Sum squared resid & 0.021560 & \multicolumn{2}{|c|}{ Schwarz criterion } & -3.946722 \\
\hline Log likelihood & 66.00323 & \multicolumn{2}{|c|}{ Hannan-Quinn criter. } & -4.073781 \\
\hline F-statistic & 20.49094 & \multicolumn{2}{|c|}{ Durbin-Watson stat } & 0.573279 \\
\hline Prob(F-statistic) & 0.000001 & & & \\
\hline
\end{tabular}

Source: Generated by the researcher from annual reports 2012-2016 using Eview version 8.0.

debt and return on asset because the R-square and adjusted R-square are greater than $50 \%$ level of significance as shown in the above analysis which is $70 \%(0.70)$ and $67 \%(0.67)$, with positive p-value of 0.9059 which is greater than $5 \%$ level of significance, so the null hypothesis is thereby accepted. It is therefore concluded that Long term debts have no significant impact on the financial performance of listed firms in the Nigeria consumer goods industry.

Table 3 shows that EQT has a positive relationship of 2.76 with ROS and the p-value of STD shows the perfect relationship of 0.0067 and the relationship is significance because the p-value is less than $0.05(5 \%)$ level of significance.

\section{Hypothesis III}

$\mathrm{H}_{03}$ : Equity does not have significant impact on financial performance of listed firms in the Nigeria consumer goods industry.

Based on the above analysis, there is positive relationship between Equity and return on asset because the R-square and adjusted R-square are greater than 50\% level of significance as shown in the above analysis which is $78 \%(0.78)$ and $75 \%$ (0.75), with positive p-value of 0.0067 which is less than $5 \%$ level of significance, so the null hypothesis is thereby rejected. It is therefore concluded that Equity has significant impact on the financial performance of listed firms in the Nigeria consumer goods industry.

\subsection{Research Contribution}

This research has made a contribution to the body of knowledge. The findings of 
Table 3. Regression Result of EQT and ROA.

Dependent Variable: ROA

Method: Least Squares

Date: 12/21/17 Time: 12:19

Sample: 130

Included observations: 30

\begin{tabular}{ccccc}
\hline Variable & Coefficient & Std. Error & t-Statistic & Prob. \\
\hline EQT & $2.76 \mathrm{E}-10$ & $9.38 \mathrm{E}-11$ & 2.945272 & 0.0067 \\
C & -0.007552 & 0.029158 & -0.258985 & 0.7977 \\
AGE & $-4.29 \mathrm{E}-06$ & 0.000722 & -0.005949 & 0.9953 \\
ROE & 0.003072 & 0.000334 & 9.205505 & 0.0000 \\
\hline R-squared & 0.777003 & Mean dependent var & 0.074333 \\
Adjusted R-squared & 0.751272 & S.D. dependent var & 0.050013 \\
S.E. of regression & 0.024943 & Akaike info criterion & -4.420912 \\
Sum squared resid & 0.016175 & Schwarz criterion & -4.234086 \\
Log likelihood & 70.31369 & Hannan-Quinn criter. & -4.361145 \\
F-statistic & 30.19778 & Durbin-Watson stat & 0.553919 \\
Prob(F-statistic) & 0.000000 & &
\end{tabular}

Source: Generated by the researcher from annual reports 2012-2016 using Eview version 8.

the study show that Short term debts have no significant impact on the financial performance of listed firms in the Nigeria consumer goods industry. It was also discovered that Long term debts have no significant impact on the financial performance of listed firms in the Nigeria consumer goods industry. It was also discovered that Equity has significant impact on the financial performance of listed firms in the Nigeria consumer goods industry. These findings will be of useful to the following stakeholders for right decision making:

Management; this research will assist management of various consumer goods industries to ascertain the best optimal capital structure.

Investors and fund Providers; this research work will help the investors and fund providers to have knowledge of capital structure and know which firm will be more profitable to invest in and provide fund.

Prospecting Researchers; this study will serve as a handy as it will serve as a basis for literature to future research in the area of capital structure and firm's performance generally. Students and other research on this area will find this study of great importance as source of information needed as it will add to the existing body of knowledge.

Financial Analysts; these are users that earn living by analyzing financial statement. The research would serve as a guide to financial analysts to enable them advice their client on the best optimal capital structure to adopt.

\subsection{Summary of Hypotheses}

\section{Hypothesis I}


$\mathrm{H}_{01}$ : Short term debt does not have significant impact on the financial performance of listed firms in the Nigeria consumer goods industry.

From the analysis, it was found that there is positive relationship between Short term debt and return on asset, therefore concluded that Short term debts have no significant impact on the financial performance of listed firms in the Nigeria consumer goods industry.

\section{Hypothesis II}

$\mathrm{H}_{02}$ : Long term debt does not have significant impact on financial performance of listed firms in the Nigeria consumer goods industry.

From the analysis, it was found that there is positive relationship between Long term debt and return on asset, therefore concluded that Long term debts have no significant impact on the financial performance of listed firms in the Nigeria consumer goods industry.

\section{Hypothesis III}

$\mathrm{H}_{03}$ : Equity does not have significant impact on financial performance of listed firms in the Nigeria consumer goods industry.

From the analysis, it was found that there is positive relationship between Equity and return on asset, therefore concluded that Equity has significant impact on the financial performance of listed firms in the Nigeria consumer goods industry.

\section{Conclusion and Recommendation}

\subsection{Conclusion}

This research seeks to examine the impact of capital structure on financial performance of listed firm in the Nigeria consumer goods industry. This subject has been widely researched over time and different results have been discovered in different locations. This study looked strictly at the consumer goods industries quoted on the Nigerian Stock Exchange (NSE) as at 31 December, 2016 and with sample size of six (6) listed companies between 2012 and 2016. The study also seeks to fill the gap in other works done by researchers in this field who have used Nigeria as a case study. Based on this finding:

1) It was discovered that Short term debts have no significant impact on the financial performance of listed firms in the Nigeria consumer goods industry.

2) It was also discovered that Long term debts have no significant impact on the financial performance of listed firms in the Nigeria consumer goods industry.

3) It was also discovered that Equity has significant impact on the financial performance of listed firms in the Nigeria consumer goods industry.

4) The analysis done also revealed that there are other things that majorly affect capital structure than the independent variables (short term debt, long term debt and shareholders' fund) used in this study.

\subsection{Recommendation}

Based on the finding of the result, the following actions are recommended. 
1) Long term debt finance is mostly used by highly tangible firms; hence policies that would encourage growing firms accumulate tangible should be pursed; hence tax rebate and exemption can be granted.

2) To maximize the market value, the major focus on quoted firm in Nigeria when deciding their choice of capital structure is to establish positive significant relationship between their capital choice majority total debt and debt equity mix and their performance as revealed in the finding of this study.

3) Managers should not pay their total attention to capital structure and ignore other things that can improve their performance generally.

4) In making a decision on what the composition of their capital structure will be, companies should look critically and make comparison between the cost of obtaining a particular source of capital and the benefit that can be derived from it instead of making capital structure decisions on baseless generalizations. This will help managers ensure that there will be a gain at the end of the day.

\section{Conflicts of Interest}

The author declares no conflicts of interest regarding the publication of this paper.

\section{References}

[1] Pandey, I.M. (2005) Financial Management. 9th Edition, Vikas Publishing, New Delhi.

[2] Adetifa, S.B. (2005) Corporate Finance and Investment Strategy. The Chatered Institute of Bankers of Nigeria, Lagos.

[3] Erhirhie, W.U.O. (2009) Fundamentals of Financial Management and Investment Analysis. Justice Jeco Press and Publishers Ltd., Benin City.

[4] Shetty, A.G., McGrath, F.J. and Hammerbacher, I.M. (1995) Finance, an Integrated Global Approach. Richard D. Irwin Inc., in Conjunction with Austen Press, Burr Ridge.

[5] Brealey, R.A. and Myers, S.C. (2001) Principles of Corporate Finance. Sixth Edition, McGraw-Hill, Burr Ridge.

[6] Benito, A. (2003) The Capital Structure Decisions of Firms: Is There a Perking Order? Banco de España, Madrid.

[7] Baskin, J. (1989) An Empirical Investigation of the Pecking Order Hypothesis. Financial Management, 19, 26-35. https://doi.org/10.2307/3665695

[8] Akinsulire, O. (2002) Financial Management. Ceemol Nigeria Limited, Lagos.

[9] Barton, S.L. (2001) Capital Structure Decisions in Privately Held Firms: A Summary of Owner Interviews. Working Paper, College of Business Administration, University of Cincinnati, Cincinnati.

[10] Rayan, K. (2008) Financial Leverage and Firm Value. Gordon Institute of Business Science, University of Pretoria, Pretoria.

[11] Myers, S.C. (1984) The Capital Structure Puzzle. Journal of Finance, 39, 575-592. https://doi.org/10.3386/w1393

[12] Uremadu, S. (2004) Financial Management (Concepts, Analysis and Applications). Precision Publishers Limited, Enugu. 
[13] Damodaran, A. (1999) Applied Corporate Finance. John Wiley and Sons Inc., New York.

[14] (2010) Dictionary of Accounting and Finance. Bloomsbury Information Ltd., London.

[15] Izedonmi, P.F. (2004) A Manual for Academic and Professional Research. Bamadek Prints, Lagos.

[16] Brealey, R.A., Myers, S.C. and Allen, F. (2006) Corporate Finance. Eighth Edition, McGraw-Hill, Inc., New York.

[17] Chenesai, R.E. (2009) Determinants of Capital Structure of Small and Medium Enterprises in the Buffalo City Municipality, Eastern Cape Province, South Africa. Faculty of Management and Commerce at the University of Fort Hare, Alice.

[18] Chenesai, R.E. (2010) Determinants of Capital Structure of Small and Medium Enterprises in the Buffalo City Municipality, Eastern Cape Province, South Africa. African Journal of Business Management, 4, 3968-3977.

[19] Richard, et al. (2009) Measuring Organizational Performance: Towards Methodological Best Practice. Journal of Management, 35, 718-721. https://doi.org/10.1177/0149206308330560

[20] Onaolapo, A.A. and Kajola, S.O. (2010) Capital Structure and Firm Performance: Evidence from Nigeria. European Journal of Economics, Finance and Administrative Sciences, 25, 70-82.

[21] Rajan, G.R. and Zingales, L. (1995) What Do We Know about Capital Structure? Some Evidence from International Data. Journal of Finance, 50, 1421-1460. https://doi.org/10.1111/j.1540-6261.1995.tb05184.x

[22] Delcoure, N. (2007) The Determinants of Capital Structure in Transitional Economies. International Review of Economics and Finance, 16, 400-415. https://doi.org/10.1016/j.iref.2005.03.005

[23] Dare, F.D. and Sola, O. (2010) Capital Structure and Corporate Performance in Nigeria Petroleum Industry: Panel Data Analysis. Journal of Mathematics and Statistics, 6, 168-173. https://doi.org/10.3844/jmssp.2010.168.173

[24] Stulz, R. (2011) Managerial Discretion and Optimal Financing Policies. Journal of Financial Economic, 26, 3-27. https://doi.org/10.1016/0304-405X(90)90011-N 


\section{Appendix}

\section{Appendix 1. Data for the Analysis}

\begin{tabular}{|c|c|c|c|c|c|c|}
\hline $\mathrm{S} / \mathrm{N}$ & ROA & $\mathrm{ROE}$ & STD & LTD & AGE & EQT \\
\hline 1 & 0.14 & 36.36 & $29,354,910$ & $8,513,058$ & 47 & $40,352,504$ \\
\hline 2 & 0.10 & 25.77 & $42,737,998$ & $8,796,183$ & 48 & $46,039,111$ \\
\hline 3 & 0.07 & 21.25 & $38,552,684$ & $27,429,985$ & 49 & $45,061,717$ \\
\hline 4 & 0.06 & 16.13 & $39,921,635$ & $12,250,754$ & 50 & $48,341,376$ \\
\hline 5 & -0.01 & -4.84 & $62,663,423$ & $14,034,546$ & 51 & $41,660,605$ \\
\hline 6 & 0.03 & 16.28 & $28,579,668$ & $2,313,776$ & 26 & $10,307,595$ \\
\hline 7 & 0.05 & 22.21 & $26,896,882$ & $4,997,684$ & 27 & $12,577,980$ \\
\hline 8 & 0.12 & 37.13 & $15,871,803$ & $1,433,469$ & 28 & $17,328,695$ \\
\hline 9 & 0.11 & 29.77 & $31,083,848$ & $4,433,469$ & 29 & $23,933,633$ \\
\hline 10 & 0.05 & 13.51 & $33,258,232$ & $1,520,205$ & 30 & $24,779,594$ \\
\hline 11 & 0.09 & 17.24 & $16,242,435$ & 0.00000 & 36 & $20,039,356$ \\
\hline 12 & 0.14 & 25.10 & $13,541,296$ & 0.00000 & 37 & 23994931 \\
\hline 13 & 0.07 & 16.76 & $11,742,702$ & 153,243 & 38 & $12,749,451$ \\
\hline 14 & 0.04 & 9.39 & $11,104,368$ & 0.00000 & 39 & $12,285,297$ \\
\hline 15 & -0.01 & -2.68 & $12,718,086$ & 0.0000 & 40 & $11,056,734$ \\
\hline 16 & 0.15 & 40.71 & $61,692,692$ & $45,000,000$ & 39 & $93,447,892$ \\
\hline 17 & 0.17 & 38.34 & $69,832,649$ & $9,000,000$ & 40 & $112,359,185$ \\
\hline 18 & 0.12 & 24.73 & $83,513,452$ & $24,670,000$ & 41 & $171,964,263$ \\
\hline 19 & 0.11 & 22.08 & $107,460,990$ & 0.000000 & 42 & $172,321,503$ \\
\hline 20 & 0.08 & 17.13 & $112,054,921$ & $17,000,000$ & 43 & $165,913,768$ \\
\hline 21 & 0.16 & 56.81 & $19,312,035$ & 145,183 & 39 & $10,043,524$ \\
\hline 22 & 0.11 & 49.87 & $26,690,176$ & 782,074 & 40 & $9,639,695$ \\
\hline 23 & 0.05 & 32.26 & $31,125,307$ & 762,602 & 41 & $7,478,808$ \\
\hline 24 & 0.02 & 14.90 & $34,505,057$ & 591,055 & 42 & $8,003,253$ \\
\hline 25 & 0.04 & 26.28 & $52,977,778$ & 414,275 & 43 & $11,689,943$ \\
\hline 26 & 0.06 & 18.90 & $40,350,298$ & 276,066 & 34 & $49,996,000$ \\
\hline 27 & 0.03 & 9.14 & $99,331,923$ & $39,863,248$ & 35 & $82,485,250$ \\
\hline 28 & 0.02 & 6.42 & $114,559,458$ & $48,614,076$ & 36 & $83,559,432$ \\
\hline 29 & 0.02 & 9.69 & $156,501,229$ & $55,260,645$ & 37 & $87,410,395$ \\
\hline 30 & 0.04 & 15.06 & $167,660,360$ & $48,009,715$ & 38 & $95,765,774$ \\
\hline
\end{tabular}

